\title{
Needs of family members of patients with cardiovascular diseases under intensive care
}

\author{
Necessidades de familiares de pacientes com agravos cardiovasculares em tratamento \\ intensivo
}

Maicon Henrique Lentsck ${ }^{1}$, Talita Mendes dos Santos ${ }^{2}$, Tatiane Baratieri ${ }^{1}$, Calíope Pilger ${ }^{3}$, Érica de Brito Pitilin ${ }^{4}$, Leticia Gramazio Soares ${ }^{1}$

Objective: to analyze the needs of family members of patients hospitalized for cardiovascular diseases in an intensive care unit. Methods: a cross-sectional study in which the Inventory of Needs and Stressors of Family Members in Intensive Care was applied to 70 family members. Data were analyzed using descriptive statistics. Results: the needs of family members, according to the importance dimension, presented greater emphasis on the safety domain and lesser on comfort. As for the satisfaction dimension, the overall mean was higher in the safety domain and lower in the proximity domain. Conclusion: family needs presented higher means for satisfaction; safety was the best evaluated domain, and comfort and proximity were the worst.

Descriptors: Needs Assessment; Family Relations; Intensive Care Units; Cardiovascular Diseases.

Objetivo: analisar as necessidades de familiares de pacientes hospitalizados por doença cardiovascular em unidade de terapia intensiva. Métodos: estudo transversal, em que se aplicou o Inventário das Necessidades e Estressores de Familiares em Terapia Intensiva a 70 familiares. Dados analisados por meio de estatística descritiva. Resultados: as necessidades dos familiares, segundo a dimensão importância, apresentou maior destaque para o domínio segurança e menor para o conforto. Para dimensão satisfação, a média global foi maior no domínio segurança e menor no domínio proximidade. Conclusão: as necessidades de familiares apresentaram médias maiores para importância em relação à satisfação, segurança foi o domínio melhor avaliado, conforto e proximidade foram os piores.

Descritores: Determinação de Necessidades de Cuidados de Saúde; Relações Familiares; Unidades de Terapia Intensiva; Doenças Cardiovasculares.

\footnotetext{
${ }^{1}$ Universidade Estadual do Centro-Oeste. Guarapuava, PR, Brazil.

${ }^{2}$ Hospital de Caridade São Vicente de Paulo. Guarapuava, PR, Brazil.

${ }^{3}$ Universidade Federal de Goiás. Catalão, GO, Brazil.

${ }^{4}$ Universidade Federal da Fronteira Sul. Chapecó, SC, Brazil.

Corresponding author: Maicon Henrique Lentsck

Rua Simeão Varela de Sá, 03 - Vila Carli, CEP: 85040-080. Guarapuava, PR, Brazil. E-mail: maiconlentsck@yahoo.com.br
} 


\section{Introduction}

Amidst discussions about improving patient safety and the performance of health care providers, attention to the needs of the families of patient has been increasingly valued in modern days ${ }^{(1-2)}$. Considering that the family is a group that is united by affective ties and the feeling of belonging, the hospitalization in an intensive care unit can cause imbalance in the family structure ${ }^{(2)}$. The family plays an important role in the recovery of patients, but their needs are often disregarded, even though they are known to bring affective safety, tranquility, and the effect of minimizing emotional tension ${ }^{(3)}$.

Such needs are physical and emotional situations experienced when a family member is admitted to an intensive care unit ${ }^{(4)}$. In the intensive care environment, patients are in complex conditions, with different clinical profiles, and they need technological support to recover ${ }^{(5)}$. Studies on nursing care for patients with cardiovascular diseases stand out in this context ${ }^{(6)}$. In view of the high prevalence, responsible for 17.8 million deaths in $2017^{(4)}$, and their chronic character, cardiovascular diseases are capable of generating important functional impairments; in acute and emergent situations, intensive care is indispensa$\mathrm{ble}^{(7)}$.

The recovery of patients with cardiovascular diseases can be long and difficult, and intensive care does not always mean a positive outcome in terms of importance and satisfaction. The need for high-tech support and treatment with specialized human and material resources, patient safety, and the needs of family members represent important factors of care provision, and they merit a unique space in the performance of the nursing team. Such needs have been discussed in several types of patients ${ }^{(1-2)}$, but they have not yet been explored among relatives of patients with cardiovascular diseases.

Comprehensive nursing care for critically ill patients requires nurses to understand the disease, the families, and how the hospitalization affects their nee- $\mathrm{ds}^{(5,8)}$. For this reason, care should also focus on the needs of family members, helping them to understand, accept and confront the disease, the treatment and its consequences ${ }^{(3,8)}$, especially in the case of cardiovascular diseases, which are chronic.

The interaction with the family and the perspective focused on the comprehensive care of individuals direct health professionals, especially nurses, to meet and satisfy the needs of the relatives of critical patients $^{(3)}$ in the various dimensions of the human being ${ }^{(5)}$.It is therefore imperative that nurses know the needs of family members of adult patients hospitalized in intensive care units. The study was based on the assumption that relatives of patients hospitalized for cardiovascular diseases have greater needs, because the patients present a chronic disease with physical and mental impairment, i.e. a cardiac dysfunction ${ }^{(9)}$. Thus, the objective of the present study was to analyze the needs of family members of patients hospitalized for cardiovascular disease in an intensive care unit.

\section{Methods}

Cross-sectional study carried out by means of a hospital survey with relatives of patients with cardiovascular disease hospitalized in an intensive care unit in the city of Guarapuava, Paraná, Brazil. The sector had 10 beds at the time of the study, and is a regional reference.

The following criteria were adopted to inclusion in the study: a) being a family member of a patient with cardiovascular disease with 24 and 96 hours of hospitalization; b) having ties of consanguinity or affective bond with a close relationship with the patient (condition informed by the participant); c) age equal to or greater than 18 years; d) having visited the patient at least once; (e) presenting conditions to respond the questions of the instrument. Family members of patients with cardiovascular disease were excluded when this was a secondary diagnosis.

Sample calculation was based on the 220 admissions in the intensive care unit for cardiovascular 
disease in the first half of 2016, considering a significance level of $95.0 \%$ and a maximum error of $10.0 \%$, totaling a minimum number of 68 participants. There were no refusals in the final sample, which was composed of 70 participants, one per patient.

Data were collected from October 2016 to March 2017 by one of the researchers, before or after the visit, in a private room near the intensive care unit. A semi-structured questionnaire addressing sociodemographic and economic information was used during the interview, as well as the Inventory of Needs and Stressors of Family Members in Intensive Care (INEFTI) $^{(8)}$, an instrument built based on the Critical Care Family Needs Inventory (CCFNI).

The INEFTI presents a cross-cultural validated version for the Brazilian population ${ }^{(10)}$. It is composed of 43 items aimed at the identification of family needs in terms of degree of importance and level of satisfaction, varying from 1 to 4 points, where the higher the value, the higher is the importance and satisfaction. It is organized into five domains, capable of assessing the need for information; safety; proximity; support and comfort of relatives of patients under intensive care. Scores were obtained through the mean of the answers; a mean score $\geq 3$ was adopted as indicating greater importance and satisfaction ${ }^{(10)}$.

Descriptive statistics (mean, standard deviation, median, relative and absolute frequency, minimum and maximum values) were used to characterize family members, as well as mean scores in INEFTI dimensions and domains. The reliability of the instrument was analyzed by the internal consistency, using the Cronbach's Alpha coefficient, adopting a lower limit of 0.7. Data were double-typed into a digital document and analyzed in the Statistical Package for the Social Sciences, version 20.0.

The study was approved by the Research Ethics Committee of the State University of the Mid-West, according to opinion $\mathrm{n}^{0} 1,156,378$ and Certificate of Presentation for Ethical Appreciation no 47072915.7.0000.0106.

\section{Results}

Of the 70 relatives surveyed, 41 were female (58.5\%), 33 were in the age group 18 to 39 years (47.2\%); and 33 in the age group 40 to 64 years, (47.2\%); 18 had complete high school (25.7\%); 40 were married (57.1\%); and 47 were Catholics (67.1\%) (Table 1).

Table 1 - Distribution of sociodemographic and economic variables of relatives of patients with cardiovascular diseases hospitalized in an intensive care unit

\begin{tabular}{lc}
\hline Variables & $\mathbf{n}(\%)$ \\
\hline Sex & \\
Male & $29(41.4)$ \\
Female & $41(58.6)$ \\
Age group (years) & \\
18 to 39 & $33(47.2)$ \\
40 to 64 & $33(47.2)$ \\
$>65$ & $4(5.6)$ \\
Schooling & \\
Illiterate & $1(1.4)$ \\
Incomplete elementary school & $15(21.4)$ \\
Complete elementary school & $14(20.2)$ \\
Incomplete high school & $4(5.7)$ \\
Complete high school & $18(25.7)$ \\
Incomplete superior education & $3(4.2)$ \\
Complete superior education & $6(8.5)$ \\
Post-graduation & $9(12.9)$ \\
Marital state & $2(2.8)$ \\
Single & $2(2.8)$ \\
Married & $14(20.0)$ \\
Consensual union & $12(17.2)$ \\
Separated & $1(1.4)$ \\
Divorced & \\
Widowed & \\
Religion & \\
Evangelical & \\
Catholic & \\
Other & \\
\hline
\end{tabular}


Table 2 describes the needs of family members, according to the importance and satisfaction dimensions and their domains. In the importance dimension, we observed a mean of $3.54 \pm 0.30$ and close means in all domains, with emphasis on safety (3.78 \pm 0.29 ) and comfort (3.38 \pm 0.44 ) with the highest and lowest mean, respectively. In the satisfaction dimension, the overall mean was $2.96 \pm 0.47$, with emphasis on safety $(3.30 \pm 0.57)$ and proximity $(2.64 \pm 0.61)$, with the highest and lowest mean, respectively. The reliability of the responses in the INEFTI presented adequate internal consistency and homogeneity, both for Importance (0.92) and satisfaction (0.93).

Table 2 - Needs of relatives of patients with cardiovascular diseases hospitalized in an intensive care unit

\begin{tabular}{|c|c|c|c|c|c|}
\hline Domains & $\begin{array}{l}\text { Total } \\
\text { mean }\end{array}$ & $\begin{array}{l}\text { Minimum- } \\
\text { Maximum }\end{array}$ & $\begin{array}{l}\text { Medi- } \\
\text { an }\end{array}$ & $95 \% \mathrm{CI}^{*}$ & $\begin{array}{c}\text { Cronbach's } \\
\text { Alfa }\end{array}$ \\
\hline \multicolumn{6}{|l|}{ Importance } \\
\hline Safety & $3.78 \pm 0.29$ & 9 3.64-3.87 & 3.93 & $3.96-4.00$ & 0.84 \\
\hline Information & $3.66 \pm 0.31$ & 3.36-3.84 & 3.75 & $3.62-3.87$ & 0.67 \\
\hline Proximity & $3.56 \pm 0.34$ & 3.23-3.83 & 3.67 & $3.56-3.67$ & 0.65 \\
\hline Support & $3.40 \pm 0.38$ & $2.67-3.70$ & 3.38 & $3.23-3.61$ & 0.80 \\
\hline Comfort & $3.38 \pm 0.44$ & 3.17-3.64 & 3.50 & $3.17-3.67$ & 0.62 \\
\hline Total & $3.54 \pm 0.30$ & $2.67-3.87$ & 3.58 & $3.50-3.71$ & 0.92 \\
\hline \multicolumn{6}{|l|}{ Satisfaction } \\
\hline Safety & $3.30 \pm 0.57$ & 7.09-3.50 & 3.43 & $3.28-3.57$ & 0.81 \\
\hline Support & $3.04 \pm 0.45$ & $2.27-3.50$ & 3.00 & $2.88-3.19$ & 0.74 \\
\hline Information & $2.96 \pm 0.61$ & 2.33-3.33 & 3.00 & $2.67-3.12$ & 0.79 \\
\hline Comfort & $2.86 \pm 0.52$ & 2.27-3.34 & 2.83 & 2.83-2.91 & 0.61 \\
\hline Proximity & $2.64 \pm 0.61$ & $2.31-3.23$ & 2.67 & $2.44-2.89$ & 0.77 \\
\hline Total & $2.96 \pm 0.47$ & $2.27-3.50$ & 2.96 & $2.84-3.10$ & 0.93 \\
\hline
\end{tabular}

${ }^{*}$ CI: Confidence interval

Table 3 presents the main needs of family members described according to the importance and satisfaction dimensions. The highest means for importance were obtained for: "To feel there is hope for improvement of the patient" (3.87 \pm 0.33 ), "To know why treatments were done to the patient" (3.84 \pm 0.36 ), and "To be informed at home about changes in the patient's condition" (3.83 \pm 0.38$)$. Regarding sa- tisfaction, the items with the highest response means were: "To know who can give the information I need" $(3.76 \pm 1.04)$, "To be sure that the best possible treatment is being given to the patient" $(3.50 \pm 0.69)$, and "To have friends around to give support" (3.50 \pm 0.77 ) (Table 3).

Table 3 - Main needs of relatives of patients with cardiovascular disease in intensive care unit, according to importance and satisfaction

\begin{tabular}{|c|c|c|}
\hline Items & Needs & $\begin{array}{c}\text { Mean } \pm \\
\text { standard } \\
\text { deviation }\end{array}$ \\
\hline \multicolumn{3}{|c|}{ Greater Importance } \\
\hline 14-Safety & $\begin{array}{l}\text { To feel there is hope for improvement of the } \\
\text { patient }\end{array}$ & $\mathrm{e} 3.87 \pm 0.33$ \\
\hline 13-Information & $\begin{array}{l}\text { To know why treatments were done to the } \\
\text { patient }\end{array}$ & $\mathrm{e} 3.84 \pm 0.36$ \\
\hline 38-Proximity & $\begin{array}{l}\text { To be informed at home about changes in the } \\
\text { patient's condition }\end{array}$ & $\mathrm{e} 3.83 \pm 0.38$ \\
\hline 1- Safety & To know the patient's chances of improvement & $\mathrm{t} 3.83 \pm 0.38$ \\
\hline 41-Safety & $\begin{array}{l}\text { To be informed about everything that relates } \\
\text { to the evolution of the patient }\end{array}$ & s $3.80 \pm 0.40$ \\
\hline \multicolumn{3}{|l|}{ Lower Importance } \\
\hline 43-Proximity & To have a waiting room near the patient & $3.23 \pm 0.98$ \\
\hline 8- Comfort & To have food and refreshments nearby & $3.20 \pm 0.86$ \\
\hline 20-Comfort & $\begin{array}{l}\text { To have comfortable furniture in the waiting } \\
\text { room of the Intensive Care Unit }\end{array}$ & $g_{3.17 \pm 0.83}$ \\
\hline 7- Support & $\begin{array}{l}\text { To talk about negative feelings related to what } \\
\text { is happening }\end{array}$ & $\mathrm{t} 3.10 \pm 0.87$ \\
\hline 18-Support & $\begin{array}{l}\text { To have a place where you can be alone while } \\
\text { in the hospital }\end{array}$ & $2.67 \pm 1.08$ \\
\hline \multicolumn{3}{|l|}{ Greater Satisfaction } \\
\hline 11-Information & To know who can give the information I need & $3.76 \pm 1.04$ \\
\hline 17-Safety & $\begin{array}{l}\text { To be sure that the best possible treatment is } \\
\text { being given to the patient }\end{array}$ & s $3.50 \pm 0.69$ \\
\hline 12-Support & To have friends around to give support & $3.50 \pm 0.77$ \\
\hline 26-Support & $\begin{array}{l}\text { To be accompanied by a professional, friend } \\
\text { or family member during the visit }\end{array}$ & $d 3.47 \pm 0.63$ \\
\hline 14-Safety & $\begin{array}{l}\text { To feel there is hope for improvement of the } \\
\text { patient }\end{array}$ & $3.46 \pm 0.87$ \\
\hline \multicolumn{3}{|l|}{ Lower Satisfaction } \\
\hline 10- Proximity & To be allowed to visit the patient at any time & $2.37 \pm 0.98$ \\
\hline 4- Information & $\begin{array}{l}\text { To have a person who can give information } \\
\text { by phone }\end{array}$ & $2.33 \pm 1.13$ \\
\hline 38-Proximity & $\begin{array}{l}\text { To be informed at home about changes in the } \\
\text { patient's condition }\end{array}$ & $2.31 \pm 1.19$ \\
\hline 32- Comfort & To have toilet facilities near the waiting room & $2.27 \pm 1.16$ \\
\hline 35-Support & To be informed about religious services & $2.27 \pm 1.07$ \\
\hline
\end{tabular}


Regarding the needs with the lowest mean, in the importance dimension, it was "To have a place where you can be alone while in the hospital" (2.67 \pm 1.08), "To talk about negative feelings related to what is happening" ( $3.10 \pm 0.87)$, and "To have comfortable furniture in the waiting room of the Intensive Care Unit" (3.17 \pm 0.83$)$. As for the satisfaction dimension, the lowest means were found for: "To be informed about religious services" (2.27 \pm 1.07$)$, "To have toilet facilities near the waiting room" $(2.27 \pm 1.16)$, and "To be informed at home about changes in the patient's condition " (2.31 \pm 1.19$)$ (Table 3).

\section{Discussion}

A limitation to be pointed in this study was the sample size. In spite of this, the results bring important information about the demands of relatives, presenting subsidies for health care provision. Thus, the importance of applying the INEFTI in larger samples of other groups of patients, sociocultural contexts, and health services with different characteristics is reiterated.

This is the first study to identify the needs of family members of people with cardiovascular diseases hospitalized in intensive care units in Brazil. The study contributes to the practice of professionals working in this sector, considering the family unit as an object of care. The sociodemographic characteristics indicate that data on schooling, income, marital status, and religion were similar to other studies ${ }^{(8)}$, demonstrating homogeneity in the sample even among populations of different regions. For the population with cardiovascular diseases, the family needs proposed by the INEFTI indicated adequate reliability indices in terms of importance and satisfaction, corroborating with Saudi published data ${ }^{(11)}$.

The importance dimension, as a parameter of greater significance for families, reflects that safety, information and proximity are in fact real needs, greater than support and comfort. It is understood that sa- fety is a necessity that is related to the feeling of being safe, with lower level of anxiety and fear regarding the conditions of the hospitalized relative ${ }^{(12)}$.

Feeling confident about the hope of improvement of the patient's condition and about the treatment provided makes the family members to believe that all will be well, even if feelings such as anxiety and distress are present during hospitalization ${ }^{(13)}$. These feelings are frequent in patients with the profile studied, such as what was found in a study with preoperative cardiac patients, which identified a severe level of anxiety, fear, and difficulty to accept the problem ${ }^{(14)}$. As a consequence, family members of patients grieve and experience insecurity and fear.

Measures such as open visits, covering objective and comprehensible information regarding the patient's progress, the provision of information related to the daily care offered to the patient in an intensive care unit, as well as guidelines that contribute to the patient's well-being deserve urgent implementation in this environment ${ }^{(12)}$. The need for information about the patient's health condition defines better the feelings of the patient's relative about recovery; however, in order to feel embraced and informed, relatives need clarification of doubts and concerns. For this reason, the health team must be accessible to meet this need ${ }^{(5)}$. It should be noted that, for relatives, it is not enough to receive the information. The way this information is transmitted, with kindness and tranquility in gestures and words, is paramount ${ }^{(15)}$.

The lower importance declared by family members with cardiovascular diseases for the support and comfort domains corroborates with data from the literature with family members hospitalized for all types of injuries, regarding the neglect of their own needs or the fact that they are not recognized as important, when judging that all the care should be directed to the recovery of their relatives ${ }^{(8)}$.

Regarding family needs, according to the satisfaction dimension, the highest means identified showed that the family members felt safe and emotio- 
nally supported. Regarding safety, similar results were found in a South African study with trauma patients, in which the family members presented a higher degree of satisfaction for the safety domain, followed by comfort and proximity ${ }^{(16)}$.

The satisfaction of family members is an important aspect in the evaluation of the quality of care offered in health institutions, being an essential part of the responsibilities of health professionals who work in intensive care ${ }^{(17)}$. However, domains with lower satisfaction, especially proximity, may be related to the little time spent with the patient and the number of visits, typical conditions of the studied site. Another explanation is related to the lack of contact with the multiprofessional team. The transference of information is left as the responsibility of physicians. The lack of interaction between the nurses and the family, as well as communication problems, due to both low level of schooling and changes in the emotional state of the family members, compromises the interrelationships with the team, increasing their anguishes ${ }^{(7)}$.

In this study, comfort was unsatisfactory, and was related to the physical structure of the hospital. Using the architecture to enable well-being is something that facilitates the work process of health professionals, complying with the guidelines of the National Humanization Policy in Brazil on the construction of embracing and harmonious ambiences that contribute to improve the care for hospitalized people and their families ${ }^{(18)}$.

In general, the needs of family members of patients with cardiovascular diseases are similar to the needs of family members of patients hospitalized for various causes ${ }^{(8,11,19)}$, especially regarding the safety domain. For this domain, this correspondence occurs due to the physical imbalance caused by any disease, as well as the impairment in the mental, psychological and social dimensions of the sick individuals ${ }^{(9)}$, affecting their quality of life and well-being, and consequently of their family members too.

It is understood that the strategies of care for the needs of family members of patients with cardiovascular diseases are similar to those for the different intensive care publics. Careful attention must be given for these needs, according to each reality and context. In this sense, studies that compare the needs of this public in different realities are significant.

Most of the needs that were considered relevant by family members come from the proactivity of the professionals to improve the relationship with them using light technologies as well as the readiness to provide timely information regarding the progress of the patient and the care measures provided. Evidence identified in a review study on the effectiveness of interventions related to the needs of family members includes the use of support groups, structured communication, journals, and pamphlet programs to meet information needs, as well as changes in physical structure and open visitation in an intensive care unit $^{(20)}$. In the meantime, the role of the nursing team in intensive care units as health educators and mobilizers of individualized and comprehensive care is of particular relevance.

However, the results indicated the need for a reorganization of the workplace, in which activities are concentrated in the technical model and directed predominantly to the patients, in parts, because they are individuals with cardiovascular diseases who require many interventions. Taking family members into account is still a challenging and arduous task for nursing professionals and for the health team that works in such a highly complex environment, in this case, in intensive care units.

The identification of these elements for family members of patients with cardiovascular diseases should be considered important by multiprofessional teams and health institutions, as it enhances the quality of the service provided through the offer of support to the family, indirectly stimulating patient recovery. In addition, the topic is intermingled with the assistance, when discusses the training of new professionals who will work in intensive care units and with 
cardiovascular diseases.

Thus, the training of nurses must overcome these barriers and raise awareness about the needs of patients' family members. Nurses must act with respect to the families, because comprehensive care in intensive care units transcends the care provided to the patients, and reaches their families, and a multidisciplinary and interdisciplinary team. Therefore, new institutional policies are necessary, with more flexible visiting hours, closer proximity of the nursing team, and greater ease to obtain information.

\section{Conclusion}

Family needs presented higher means for importance in relation to satisfaction. The most important were those related to safety and information domains. However, none of the domains was considered to be unimportant. Regarding satisfaction, it was shown that the family members were little satisfied with the proximity, comfort and information domains, but they were more satisfied with the safety and support domains.

\section{Acknowledgements}

To the Conselho Nacional de Desenvolvimento Científico and the Tecnológico e à Coordenação de Aperfeiçoamento de Pessoal de Nível Superior.

\section{Collaborations}

Lentsck MH and Santos TM contributed in the conception and design, analysis and interpretation of the data, and approval of the final version to be published. Baratieri T, Pilger C, Pitilin EB and Soares LG collaborated with writing the article, critically review of the relevant intellectual content and approval ofthe final version to be published.

\section{References}

1. Twohig B, Manasia A, Marcus AB, Oropello J, Gayton M, Gaffney C, et al. Family experience survey in the surgical intensive care unit. Appl Nurs Res. 2015; 28(4):281-4. doi: https://doi. org/10.1016/j.apnr.2015.02.009

2. Wetzig K, Mitchell M. The needs of families of ICU trauma patients: an integrative review. Intensive Crit Care Nurg. 2017; 41:63-70. doi: https://doi. org/10.1016/j.iccn.2017.02.006

3. Padilla CFF. Most Important needs of family members of critical patients in light of the Critical Care Family Needs Inventory. Invest Educ Enferm. 2014; 32(2):306-16. doi: https://doi. org/10.17533/udea.iee.v32n2a13

4. Roth GA, Abate D, Abate KH, Abay SM, Abbafati C, Abbastabar $\mathrm{H}$, et al. Global, regional, and national age-sex-specific mortality for 282 causes of death in 195 countries and territories, 1980-2017: a systematic analysis for the global burden of disease study 2017. Lancet. 2018; 392(10159):1736-88. doi: doi.org/10.1016/S0140-6736(18)32203-7

5. Sibel S, Ajghif M, Uzun Ö, Gülbil U. Expectations of relatives of Syrian patients in intensive care units in a state hospital in Turkey. J Clin Nurs. 2016; 25(15-16):2232-41. doi: doi.org/10.1111/ jocn. 13254

6. Santos MAB, Sá GGM, Caetano JÁ, Costa AB, Muniz MLC, Galindo Neto NM. Brazilian nursing dissertations and theses conducted in intensive care units. Rev Rene. 2017;18(4):521-7.doi:dx.doi. org/10.15253/2175-6783.2017000400014

7. Kasaoka S. Evolved role of the cardiovascular intensive care unit (CICU). J Intensive Care. 2017; 5:72. doi: https://dx.doi.org/10.1186\%2Fs40560-017-0271-7

8. Puggina AC, Ienne A, Carbonari KFBSF, Parejo LS, Sapatini TF, Silva MJP. Perception of communication, satisfaction and importance of family needs in the Intensive Care Unit. Esc Anna Nery. 2014; 18(2):277-83. doi: http://dx.doi. org/10.5935/1414-8145.20140040 
9. Santos JR, Reis SCCAG, Reis MCS, Soares ABAL, Juca AL. Qualidade de vida de pacientes hospitalizados com doenças cardiovasculares: possibilidades de intervenção da terapia ocupacional. Rev Interinst Bras Ter Ocup [Internet]. 2017 [citado 2019 abr. 23]; 1(5):620-33. Disponível em: https://revistas. ufrj.br/index.php/ribto/article/view/9962/pdf

10. Broek JMVD, Brunsveld-Reinders AJ, Zedlitz AMEE, Girbes ARJ, Jonge E, Arbous MS. Questionnaires on Family Satisfaction in the Adult ICU: a systematic review including psychometric properties. Crit Care Med. 2015; 43(8):1731-44. doi: http:// dx.doi.org/10.1097/CCM.0000000000000980

11. Al-Mutair AS, Plummer V, Clerehan R, O'Brien AT. Families' needs of critical care Muslim patients in Saudi Arabia: a quantitative study. Nurs Crit Care. 2014; 19(4):185-95. doi: doi.org/10.1111/ nicc.12039

12. Neves JL, Schwartz E, Guanilo MEE, Amestory SC, Mendieta MC, Lise F. Evalution of the satisfaction of families of patients cared for in intensive therapy units: integrative review. Texto Contexto Enferm. 2018: 27(2):e1800016. doi: http://dx.doi. org/10.1590/0104-070720180001800016

13. Lópes CRG, Ramos ES. Percepción de necesidades en cuidadores familiares de adultos internados en una unidad de cuidados intensivos de una institución prestadora de salud (IPS) privada en Villavicencio, Colombia. Investig. Enferm. Imagen Desarr. 2014: 16(2):81-94. doi: http://dx.doi. org/10.11144/Javeriana.IE16-2.pncf

14. Grisa GH, Monteiro JK. Aspectos emocionais do paciente cardíaco cirúrgico no período préoperatório. Gerais: Rev Interinstitucional Psicol [Internet]. 2015 [citado 2019 fev. 25]; 8(1):11130. Disponível em: http://pepsic.bvsalud.org/ scielo.php?script=sci_arttext\&pid=S1983 $82202015000100009 \& \operatorname{lng}=p t$
15. Valente CO, Fonseca GM, Freitas KS, Mussi FC. Family comfort to a relative in the intensive therapy unit. Rev Baiana Enferm. 2017; 31(2):e17597. doi: http://dx.doi.org/10.18471/rbe.v31i2.17597

16. Botes ML, Langley G. The needs of families accompanying injured patients into the emergency department in a tertiary hospital in Gauteng. Curationis. 2016; 39(1):1567. doi: https://doi. org/10.4102/curationis.v39i1.1567

17. Mahrous MS. Relating family satisfaction to the care provided in intensive care units: quality outcomes in Saudi accredited hospitals. Rev Bras Ter Intensiva. 2017; 29(2):188-94. doi: http:// dx.doi.org/10.5935/0103-507x.20170018

18. Ribeiro JP, Gomes GC, Thofehrn MB. Health facility environment as humanization strategy care in the pediatric unit: systematic review. Rev Esc Enferm USP. 2014; 48(3):530-9. doi: dx.doi.org/10.1590/ S0080-623420140000300020

19. Liew SJ, Dharmalingam TK, Ganapathy GK, Muniandy RK, Johnny NGU, Lily NG. Need domains of family members of critically-ill patients: a Borneo perspective. Borneo J Med Sci [Internet]. 2018 [cited apr. 23, 2019]; 12(2):27. Available from: https://jurcon.ums.edu.my/ojums/index.php/ bjms/article/view/1222.

20. Kynoch K, Chang A, Coyer F, McArdle A. The effectiveness of interventions to meet family needs of critically ill patients in an adult intensive care unit: a systematic review update. JBI Database System Rev Implement Rep. 2016; 14(3):181-234. doi: dx.doi.org/10.11124/JBISRIR-2016-2477 